\title{
Optimasi Kadar Kombinasi Polimer Hidroksi Propil Metil Selulosa dan Superdisintegran Crosscarmellose Sodium terhadap Daya Adhesi dan Laju Pelepasan Obat dalam Tablet Vaginal Metronidazol
}

\author{
Anugrah Elfa Yudita*, Oktavia Eka Puspita ${ }^{*}$, Adeltrudis Adelsa Danimayostu ${ }^{*}$
}

\begin{abstract}
ABSTRAK
Pengobatan yang efektif di daerah genitalia wanita harus memiliki sistem penghantaran obat yang sesuai dengan kondisi daerah vagina yang memiliki aktivitas self-cleansing. Penggunaan kombinasi polimer mukoadhesif dan superdisintegaran crosscarmellose sodium diharapkan dapat membantu penghantaran obat yang sesuai dengan kondisi vagina. Tujuan penelitian ini adalah untuk mengetahui kadar kombinasi polimer HPMC dan superdisintegran crosscarmellose sodium untuk menghasilkan daya adhesi dan laju pelepasan obat dalam tablet vaginal metronidazole yang optimum. Metode pembuatan tablet yang digunakan yakni metode kempa langsung. Pada penelitian ini digunakan 3 formula yang mempunyai kadar kombinasi yang berbeda yakni dengan perbandingan kadar kombinasi untuk formula I sebesar 30:1, formula II sebesar 30:3 dan formula III sebesar 50:1. Hasil penelitian menunjukkan bahwa untuk uji IPC dan karakteristik fisik tablet seperti laju alir, homogenitas, keseragaman bobot, keseragaman ukuran, kekerasan, kerapuhan, penetapan kadar dan waktu hancur memenuhi persyaratan penerimaan tablet. Pada uji laju pelepasan obat dengan formula I memberikan pelepasan obat sebesar $0,1257 \mathrm{mg} /$ menit setelah 4 jam jika dibandingkan dengan formula 2 dan formula 3 . Daya adhesif yang paling tinggi terdapat pada formula 3 dengan konsentrasi HPMC sebesar 50\%. Namun, ketiga formula masih memiliki daya adhesif yang masih diterima oleh persyaratan (minimal 3 jam di area vagina). Berdasarkan hasil tersebut kadar kombinasi formula yang optimum terdapat pada formula I yang mempunyai laju pelepasan yang cepat dan daya adhesif yang mampu menghambat pelepasan obat dalam waktu 4 jam.
\end{abstract}

Kata kunci: Crosscarmellose sodium, Daya adhesif, HPMC,Laju pelepasan obat, Tablet vaginal

\section{Optimization Levels Combination of Polymer Hydroxy Propyl Methyl Cellulose and Superdisintegran Sodium Crosscarmellose against Adhesion Power and Rate of Drug Release in Metronidazole Vaginal Tablets}

\begin{abstract}
Effective treatment of female genitalia should have a drug delivery systemaccording to the conditions of the vagina that has a self-cleansing activity. The use of a combination of polymer mukoadhesif HPMC and superdisintegaran crosscarmellose sodium are expected to help drug delivery that suitable to the conditions of the vagina. The purpose of this study was to determine the optimum levels combinations of HPMC and sodium crosscarmellose against power adhesion and drug release in metronidazole vaginal tablet. The tablet was made by using directly clamp method. This research consisted of 3 formula with different levels of the combination, they were 30: 1 in formula I, 30: 3 in formula II, and 50: 1 in formula III. The result showed that IPC test and physical characteristics of tablets such as flow rate, homogeneity, uniformity of weight, size uniformity, hardness, friability, disintegration time assay fulfiled the requirements of tablets. While the rate of drug release test, formula 1 provideed drug release at $0.1257 \mathrm{mg} / \mathrm{min}$ after 4 hours when compared with formula 2 and formula 3 . The highest adhesion power was in formula 3 with HPMC concentration by $50 \%$. However, all formula have shown the adhesion capacity since they fulfiled the requirements (at least of 3 hours in vaginal area). It is concluded that optimum levels of the combination is in formula 1 that have a fast release rate and the adhesion capacity that can inhibit the release of drug in 4 hours.
\end{abstract}

Keywords: Adhesion power, Drug release rate, HPMC, Sodium crosscarmellose, Vaginal tablet

* Program Studi Farmasi - FKUB

\footnotetext{
$\bowtie$ Program Studi Farmasi, Fakultas Kedokteran Universitas Brawijaya, Jalan Veteran Malang, 65145

E-mail: oktaviaekapuspita@gmail.com
} 


\section{PENDAHULUAN}

Infeksi di daerah vagina biasanya terjadi akibat bakteri dan jamur. Infeksi ini biasanya disebut dengan vaginitis yang meliputi infeksi bakteri, vulvovaginal candidiasis dan trichomoniasis. Vaginitis merupakan pembengkakan di daerah vulva vagina yang biasa diderita oleh sebagian besar wanita. ${ }^{1}$ Pengobatan yang efektif di daerah genitalia wanita harus memiliki sistem penghantaran obat yang sesuai dengan kondisi daerah vagina yang memiliki aktivitas self-cleansing. Bentuk sediaan vaginal yang memberikan efek lokal tanpa masalah stabilitas dan aplikasi, akan sangat diterima oleh pasien sehingga dapat meminimalkan efek samping dan meningkatkan kepatuhan pasien. Tablet vaginal merupakan salah satu bentuk sediaan yang bisa memberikan terapi yang efektif di daerah vaginal. ${ }^{2}$

Zat mukoadhesif pada pembuatan tablet vaginal dapat memberikan solusi dalam mempertahankan manfaat pada efek lokal. Prinsip penghantaran obat dengan sistem mukoadhesif adalah memperpanjang waktu tinggal obat pada organ tubuh yang mempunyai lapisan mukosa, sehingga konsentrasi obat terpenetrasi lebih banyak dan diharapkan akan terjadi aliran obat yang tinggi melalui jaringan tersebut. ${ }^{3}$ Beberapa tahun belakangan ini, polimer mukoadhesif yang digunakan untuk eksipien dalam tablet vaginal sedang berkembang pesat. ${ }^{4}$

Tablet vaginal memerlukan pemecahan obat secara cepat untuk memberikan kenyamanan pada saat aplikasi. Oleh karena itu perlu ditambahkan eksipien lain untuk membantu proses pemecahan obat dalam sediaan. Dalam tablet vaginal, pelepasan obat yang baik dapat ditunjang dari bahan yang mampu mengembang dan membantu disintegrasi tablet sehingga obat segera terlepas. Eksipien yang memiliki sifat tersebut yakni disintegran. Disintegran merupakan bahan atau campuran bahan yang ditambahkan dalam formulasi, untuk membantu proses pemecahan tablet menjadi partikel kecil sehingga membantu disolusi obat. ${ }^{5}$

Polimer HPMC memilki rantai panjang dan bersifat nonionik. Dalam fungsinya sebagai polimer mukoadhesif, polimer ini berikatan dengan hidrogen mukus yang ada di vagina. Bagian yang berperan dalam pengikatan ini adalah gugus hidroksil yang bertanggung jawab untuk proses adhesi. Semakin tinggi konsentrasi HPMC semakin kuat ikatan yang terbentuk dan semakin lama waktu kontak dengan mukosa daerah vagina. Akan tetapi dengan daya adhesi yang tinggi dapat menurunkan jumlah obat yang dilepaskan ke target organ. ${ }^{6}$ Oleh karena itu membutuhkan eksipien lain untuk membantu proses pelepasan obat tersebut. Bahan yang dapat digunakan yakni superdisintegran crosscarmellose sodium yang mempunyai mekanisme swelling melalui proses wicking, yakni membantu pemecahan tablet dengan menghancurkan ikatan interpartikular ketika kontak dengan air sehingga menghasilkan lapisan gel yang minimal. ${ }^{5} \mathrm{Hal}$ ini dapat membantu laju pelepasan obat dari tablet vaginal yang menggunakan mukoadhesif HPMC. 
Penggunaan kedua bahan diharapkan dapat mempercepat proses pemecahan obat tanpa didahului oleh aksi self-cleansing dari vaginal dan membantu proses swelling obat tapi mempunyai daya adhesi yang optimal serta dapat meningkatkan laju pelepasan obat. 1

Metode yang digunakan dalam membuat tablet adalah metode kempa langsung. Metode ini memiliki beberapa keuntungan diantaranya lebih ekonomis karena validasi proses lebih sedikit, dalam prosesnya tidak memerlukan kondisi lembab dan pemanasan, lebih singkat dalam prosesnya, disosiasi partikelnya sangat baik, lebih stabil, dan ukuran partikelnya merata serta memiliki waktu hancur dan disolusi yang lebih baik karena tidak melewati proses granul, tetapi langsung menjadi partikel. $^{7}$

Penelitian ini diharapkan mampu menghasilkan tablet vaginal dengan daya adhesi yang optimal dan dapat meningkatkan laju pelepasan obat.

\section{BAHAN DAN METODE}

\section{Alat dan Bahan}

Bahan yang digunakan dalam penelitian ini adalah metronidazol, HPMC, magnesiumstearat, talk, cab-osil, crosscarmellose sodium, dan microcrystalin cellulose. Alat yang digunakan dalam penelitian ini adalah alat pencetak tablet rotary, timbangan analitik, spektrofotometer UV-VIS, alat uji sifat alir, alat uji waktu hancur, alat uji kekerasan tablet, alat uji disolusi,alat uji mukoadhesive, stopwatch, kaca arloji, termometer, kuas, jangka sorong, mortir, stamper, dan gelas ukur.
Tabel 1. Desain formula tablet vaginal metronidazol

\begin{tabular}{|c|c|c|c|c|c|c|c|}
\hline Bahan & Fungsi & $\begin{array}{c}\mathrm{Fl} \\
(\%)\end{array}$ & $\begin{array}{c}\mathrm{FI} \\
(\mathbf{m g})\end{array}$ & $\begin{array}{c}\mathrm{F} \text { II } \\
(\%)\end{array}$ & $\begin{array}{c}\mathrm{F} \text { II } \\
(\mathbf{m g})\end{array}$ & $\begin{array}{c}\mathrm{F} \text { III } \\
(\%)\end{array}$ & $\begin{array}{c}\mathrm{F} \text { III } \\
(\mathbf{m g})\end{array}$ \\
\hline Metronidazol & Obat & 20 & 200 & 20 & 200 & 20 & 200 \\
\hline HPMC & $\begin{array}{c}\text { Polimer } \\
\text { mukoadhesive }\end{array}$ & 30 & 150 & 30 & 300 & 50 & 250 \\
\hline $\begin{array}{c}\text { Crosscarmellose } \\
\text { sodium }\end{array}$ & Superdisintegran & 1 & 5 & 3 & 15 & 1 & 5 \\
\hline MgStearat & Lubrikan & 1 & 5 & 1 & 5 & 1 & 5 \\
\hline Talc & Glidan & 1 & 5 & 1 & 5 & 1 & 5 \\
\hline Cab-0-Sil & Glidan & 1 & 5 & 1 & 5 & 1 & 5 \\
\hline $\begin{array}{c}\text { Microcrystalline } \\
\text { Cellulose }\end{array}$ & Diluent & $\begin{array}{c}\mathrm{Ad} \\
100 \%\end{array}$ & $\begin{array}{c}\mathrm{Ad} \\
500\end{array}$ & $\begin{array}{c}\mathrm{Ad} \\
100 \%\end{array}$ & $\begin{array}{c}\mathrm{Ad} \\
500\end{array}$ & $\begin{array}{c}\mathrm{Ad} \\
100 \%\end{array}$ & $\begin{array}{c}\mathrm{Ad} \\
500\end{array}$ \\
\hline
\end{tabular}

\section{Uji Laju Alir Massa Serbuk}

Uji ini dilakukan dengan menggunakan corong, pertama yang dilakukan yakni menyiapkan $100 \mathrm{~g}$ serbuk sampel dimasukkan ke dalam beaker glass. Kemudian masukkan serbuk dengan hati-hati, tekan dengan perlahan bagian bawah corong sehingga serbuk masuk ke dalam corong. Setelah serbuk dimasukkan, biarkan selama minimal 30 detik sebelum memulai tes untuk menghindari kemungkinan pembentukan flokulat. Lepaskan tekanan pada bawah corong, biarkan serbuk mengalir selama 10 detik. Waktu diamati dengan stopwatch dari mulai dibukanya lubang corong hingga seluruh massa serbuk mengalir melewati lubang bawah corong.

\section{Uji Homogenitas Massa Serbuk}

Uji ini dilakukan dengan menggunakan pipet mikromeritik yang dimasukkan ke bagian atas, tengah dan bawah massa serbuk selama proses pencampuran. Sejumlah gram bahan yang setara dengan $50 \mathrm{mg}$ obat diambil dilarutkan dalam $100 \mathrm{ml}$ buffer sitrat $\mathrm{pH}$ 4,8 sampai tanda batas dan dikocok selama 30 menit. Didiamkan beberapa saat, sehingga bagian yang tidak larut mengendap dan disaring dengan kertas saring. Larutan beningan dipipet $10 \mathrm{ml}$ 
ke dalam labu ukur $50 \mathrm{ml}$, lalu diencerkan dalam buffer sitrat $\mathrm{pH} 4,8$ sampai tanda batas dan dikocok selama 30 menit. Larutan dipipet sebanyak $7,5 \mathrm{ml}$ dan dimasukkan dalam labu ukur $50 \mathrm{ml}$, lalu diencerkan dalam buffer sitrat $\mathrm{pH}$ 4,8 sampai tanda batas dan dikocok selama 30 menit. Hasilnya kemudian disaring dengan kertas saring dan ditentukan kadarnya dengan spektroforometri UV/Vis dengan panjang gelombang $319 \mathrm{~nm}$.

\section{Uji Organoleptik}

Uji organoleptik dilakukan secara deskriptif dengan cara mengidentifikasi sediaan. Kemudian diamati secara visual, meliputi bentuk tablet, homogenitas warna, tekstur permukaan cacat atau tidak, dan penampilan fisik bebas dari bintik-bintik atau tidak.

\section{Uji Keseragaman Bobot}

Uji keseragaman bobot tablet vaginal metronidazol dilakukan dengan cara menimbang 20 tablet, lalu hitung bobot rata-rata tiap tablet.

\section{Uji Keseragaman Ukuran}

Uji keseragaman ukuran tablet vaginal metronidazol dilakukan dengan cara mengukur diameter pada 20 tablet dengan menggunakanhardness tester. Hasil pengukuran dicatat dan kemudian dihitung rata-ratanya.

\section{Uji Kekerasan Tablet}

Uji kekerasan tablet vaginal metronidazol dilakukan dengan 10 tablet dari masing-masing formula diukur kekerasannya dengan alat hardness tester.

\section{Uji Kerapuhan Tablet}

Uji kerapuhan tablet vaginal metronidazol dilakukan dengan 10 tablet dari masing-masing formula ditimbang dengan seksama (Wo). Sebelum ditimbang, dibersihkan permukaan tablet dari serbuk atau kotoran yang menempel. Setelah itu tablet dimasukkan ke dalam friabilator dan menjalankan alat (25 rpm sebanyak 100 kali putaran selama 4 menit). Kemudian, tablet dikeluarkan dan dibersihkan dari serbuk pada

$$
\% \text { Friabilitas }=\frac{(\mathbf{W o}-\mathbf{W t})}{\text { Wo }} \times 100 \%
$$

permukaan tablet.

Selanjutnya ditimbang kembali (Wt). Dihitung persentase kehilangan bobot sebelum dan sesudah perlakuan ( $\%$ friabilitas). ${ }^{8}$

\section{Uji Laju Pelepasan Obat}

Uji laju pelepasan obat dilakukan dengan metode keranjang. Medium disolusi terdiri dari $650 \mathrm{~mL}$ buffer sitrat (pH 4,8). Pelepasan dilakukan pada suhu $37 \pm 0.1{ }^{\circ} \mathrm{C}$, dengan kecepatan rotasi $25 \mathrm{rpm}$. Sebanyak $10 \mathrm{ml}$ sampel diambil dengan interval waktu yang telah ditentukan (tiap jam antara 30, 60, 90, 120, 180, 240 menit) dan volume diganti dengan medium yang segar. Kemudian sampel disaring melalui kertas saring Whatmanno. 40 dan dianalisis dengan spektrofotometer UV/Vis pada panjang gelombang $319 \mathrm{~nm}$.

\section{Uji Pengembangan Tablet}

Uji pengembangan tablet vaginal metronidazol dilakukan dengan 3 tablet vaginal masing-masing ditimbang $\left(\mathrm{W}_{0}\right)$ dan ditempatkan secara terpisah pada 
buffer sitrat $\mathrm{pH}$ 4,8 dan diinkubasi pada suhu $37 \pm 1{ }^{\circ} \mathrm{C}$. Pada interval waktu 15 menit, 30 menit, 1 jam, 2 jam, dan 4 jam, tablet dikeluarkan dari cawan dan kelebihan air dibuang dengan menggunakan kertas saring. Tablet yang mengembang ditimbang kembali (Wt) dan indeks pengembangan dihitung dengan menggunakan rumus berikut4:

$$
\text { Indeks Pengembangan }=\frac{\left(\mathbf{W t}-\mathbf{W}_{0}\right)}{\mathbf{W}_{0}}
$$

\section{Uji in vitro Mukoadhesif}

Daya mukoadhesif tablet diukur dengan menggunakan alat uji mukoadhesif. Metode ini menggunakan model membran mukosa. Mukosa membran dibilas dengan buffer sitrat $\mathrm{pH}$ 4,8. Kemudian diletakkan pada platform dan dijepit dengan penjepit platform. Lalu tablet dipasang pada timbangan yang sudah ditera. Sebanyak $0,1 \mathrm{ml}$ larutan buffer sitrat dilewatkan pada membran mukusa dengan syringe plastik. Tablet dan mukosa dibiarkan mengalami kontak selama 15 menit, kemudian timbangan diberi bobot. Penambahan dihentikan setelah terjadi pemutusan kontak antara tablet dengan mukosa.

\section{Uji Penetapan Kadar Metronidazol}

Uji ini dilakukan dengan menggunakan 10 tablet vaginal metronidazol yang dihancurkan hingga menjadi massa serbuk. Sejumlah gram bahan yang setara dengan $50 \mathrm{mg}$ obat diambil dilarutkan dalam $100 \mathrm{ml}$ buffer sitrat $\mathrm{pH} \mathrm{4,8}$ sampai tanda batas dan dikocok selama 30 menit. Didiamkan beberapa saat, sehingga bagian yang tidak larut mengendap dan disaring dengan kertas saring. Larutan beningan dipipet $10 \mathrm{ml}$ ke dalam labu ukur $50 \mathrm{ml}$, lalu diencerkan dalam buffer sitrat $\mathrm{pH}$ 4,8 sampai tanda batas dan dikocok selama 30 menit. Larutan dipipet sebanyak $7,5 \mathrm{ml}$ dan dimasukkan dalam labu ukur $50 \mathrm{ml}$, lalu diencerkan dalam buffer sitrat pH 4,8 sampai tanda batas dan dikocok selama 30 menit. Hasilnya kemudian disaring dengan kertas saring dan ditentukan kadarnya dengan spektroforometri UV/Vis dengan panjang gelombang $319 \mathrm{~nm}$.

\section{Uji Waktu Hancur}

Uji waktu hancur dilakukan dengan cara memasukkan 1 tablet pada masing-masing tabung dari keranjang. Tanpa menggunakan cakram pada tiap tabung, lalu alat dijalankan. Gunakan air bersuhu $37 \pm 2^{\circ} \mathrm{C}$ sebagai media. Angkat keranjang dan amati semua tablet.

\section{HASIL PENELITIAN}

Pada penelitian ini dilakukan pembuatan tablet vaginal metronidazol dengan penambahan eksipien mukoadhesif HPMC dan superdisintegran crosscarmellose sodium. HPMC digunakan sebagai agen mukoadhesif yang bertujuan memberikan daya adhesif yang tinggi pada sediaan sehingga mampu berikatan dengan mukus. Crosscarmellose sodium berfungsi sebagai superdisintegran yang diharapkan dapat memecah sediaan secara cepat sehingga mampu meningkatkan pelepasan obat pada menit-menit pertama penggunaan. Penambahan kedua eksipien ini bertujuan untuk meningkatkan laju pelepasan obat dari sediaan dengan 
tetap mempertahankan daya adhesif obat.
Pada Tabel 2 berikut ini disajikan hasil uji yang diperoleh.

Tabel 2. Hasil uji tablet vaginal metronidazol

\begin{tabular}{|l|l|l|l|}
\hline \multirow{2}{*}{ Parameter Uji } & \multicolumn{3}{|c|}{ Rerata \pm SD } \\
\cline { 2 - 4 } & \multicolumn{1}{|c|}{ FI } & \multicolumn{1}{c|}{ F III } \\
\hline Laju Alir (g/detik) & $15,165 \pm 0,685$ & $13,047 \pm 0,262$ & $14,934 \pm 0,446$ \\
\hline Homogenitas Massa Serbuk (\%) & $103,45 \pm 0,07$ & $94,18 \pm 0,06$ & $105,36 \pm 0,06$ \\
\hline Keseragaman Bobot (g) & $0,503 \pm 0,005$ & $0,513 \pm 0,004$ & $0,497 \pm 0,003$ \\
\hline Keseragaman Ukuran (cm) & $11,238 \pm 0,011$ & $11,242 \pm 0,008$ & $11,235 \pm 0,008$ \\
\hline Kekerasan (kg) & $5,710 \pm 0,825$ & $5,140 \pm 0,647$ & $4,920 \pm 0,121$ \\
\hline Kerapuhan (\%) & $0,2500 \pm 0,0003$ & $0,7200 \pm 0,0011$ & $0,7200 \pm 0,0004$ \\
\hline Laju Pelepasan Obat (mg/menit) & & & \\
\hline 30 & 0,0403 & 0,0396 & 0,0339 \\
\hline 60 & 0,0637 & 0,0606 & 0,0540 \\
\hline 90 & 0,0796 & 0,0751 & 0,0676 \\
\hline 120 & 0,1076 & 0,0862 & 0,0778 \\
\hline 180 & 0,1173 & 0,0956 & 0,0861 \\
\hline 240 & 0,1257 & 0,1038 & 0,0939 \\
\hline Indeks Pengembangan tablet & & & \\
\hline 15 & 2,86 & 2,73 & 3,63 \\
\hline 30 & 3,5 & 3,6 & 4,36 \\
\hline 60 & 4,36 & 4,5 & 4,86 \\
\hline 120 & 4,07 & 4,36 & 4,73 \\
\hline 240 & 2,96 & 3,86 & 3,7 \\
\hline In-vitro Mukoadhesive & $2,1670 \pm 0,2890$ & $2,3330 \pm 0,2890$ & $3,1670 \pm 0,2890$ \\
\hline Penetapan Kadar (\%) & $105,30 \pm 0,05$ & $96,96 \pm 0,13$ & $102,52 \pm 0,17$ \\
\hline Waktu Hancur (detik) & $23,333 \pm 2,338$ & $21,500 \pm 1,092$ & $26,667 \pm 0,816$ \\
\hline
\end{tabular}

Uji laju alir pada masing-masing formula memberikan hasil bahwa ketiga formula memiliki laju alir yang baik sesuai dengan persyaratan. Dengan demikian dapat dipastikan bahwa ketiga formula bisa dicetak menjadi tablet tanpa mempermasalahkan aliran dari massa serbuk selama proses pencetakan. Uji homogenitas massa serbuk dilakukan untuk mengetahui apakah semua bahan pada proses pencampuran telah tercampur dengan merata dalam massa serbuk. Hasil uji menunjukkan bahwa ketiga formula memenuhi persyaratan yaitu masing-masing formula homogen di bagian atas,tengah dan bawah sesuai dengan persyaratan yang telah ditentukan dengan kadar obat dalam rentang 90-110\%. Hasil tersebut menunjukkan bahwa ketiga formula memiliki konsentrasi obat dalam jumlah yang hampir sama. Formula I lebih memenuhi kriteria penerimaan dikarenakan selisih kadarnya hampir mendekati $100 \%$ jika dibandingkan formula 2 dan 3. Uji homogenitas ini juga mampu mempengaruhi efektifitas terapi. Bila jumlah obat pada tiap bagian sama diharapkan tiap tablet dapat memberikan efektifitas terapi yang sama.

Setelah dilakukan uji IPC kemudian dilakukan pencetakan tablet dengan mesin pencetak tablet single punch. Pada saat pencetakan tablet terlebih dahulu dipersiapkan mesin pencetak tablet yang digunakan sehingga mampu menghasilkan tablet dengan kondisi yang sama. Setelah tablet vaginal metronidazol terbentuk, masing-masing formula dilakukan uji sediaan tebletyakni 
uji organoleptis. Uji ini secara deskriptif melihat bentuk fisik tablet, meliputi bentuk tablet homogenitas warna dan tekstur permukaan. Uji ini dilakukan untuk memperoleh tablet vaginal metronidazol yang sesuai dengan spesifikasi yang telah ditetapkan dan memberikan rasa yang nyaman kepada pasien. Setelah dilakukan uji diperoleh hasil bahwa ketiga formula memiliki bentuk, warna dan tekstur permukaan yang sama yakni berbentuk bulat, berwarna putih tanpa bintik noda dan bertekstur halus tidak kasar.

Uji keseragaman bobot dilakukan dengan tujuan untuk mengetahui apakah tablet vaginal metronidazol yang dihasilkan memiliki bobot yang seragam. Dari uji yang dilakukan diperoleh hasil bahwa ketiga formula memiliki rerata bobot yang berbeda. Perbedaan bobot pada ketiga formula disebabkan karena konsentrasi pengisi yang ditambahkan pada tiap formula berbeda jumlahnya. ${ } \mathrm{Uji}$ keseragaman bobot masing-masing formula memenuhi persyaratan bobot yang ditentukan ( $<5 \%$ dari bobot awal) yakni antara 0,475 - 0,525 g. Uji keseragaman bobot ini untuk melihat apakah tiap tablet yang dihasilkan dari mesin pencetak tablet dapat menghasilkan tablet dengan bobot yang seragam. Hal ini diharapkan akan berpengaruh pada komposisi obat pada tiap tabletnya, sehingga efektifitas terapi dapat dicapai.

Uji keseragaman ukuran dilakukan dengan tujuan untuk mengetahui apakah tablet vaginal metronidazol yang dihasilkan memiliki ukuran yang seragam. Apabila semua tablet mempunyai ukuran yang seragam akan berpengaruh pada komposisi obat pada tiap tabletnya. Dengan demikian efek terapi dapat dicapai secara maksimal. Ketiga formula memiliki ukuran yang sama karena dihasilkan dari mesin cetak yang sama. Berdasarkan hasil uji keseragaman ukuran yang telah dilakukan didapatkan hasil bahwa masing-masing formula telah memenuhi persyaratan. Dari ketiga formula tersebut formula III mempunyai diameter yang paling mendekati diameter yang diinginkan untuk tablet dengan ukuran $500 \mathrm{mg}$.

Uji kekerasan dilakukan dengan tujuan untuk mengetahui ketahanan tablet dalam melawan tekanan mekanik seperti goncangan, kikisan dan terjadi keretakan tablet selama pembungkusan, pengangkutan dan pemakaian. Faktorfaktor yang mempengaruhi kekerasan tablet adalah tekanan kompresi dan sifat bahan yang dikempa. Kekerasan ini dipakai sebagai ukuran dari tekanan pengempaan. Semakin besar tekanan yang diberikan saat penabletan akan meningkatkan kekerasan tablet. ${ }^{9}$ Berdasarkan hasil uji kekerasan yang telah dilakukan diperoleh pada masingmasing formula memenuhi persyaratan uji kekerasan tablet. Formula I memiliki kekerasan yang paling tinggi jika dibandingkan dengan formula 2 dan 3. Bila tablet terlalu keras maka akan berpengaruh terhadap waktu hancurnya. Hal ini dapat dapat mempengaruhi pula waktu disolusi obat. ${ }^{9}$ Formula I memiliki kekerasan yang masih dapat diterima oleh persyaratan akan tetapi harus dilihat pula mengenai waktu hancur dan disolusi obat apakah dipengaruhi oleh kekerasan dari formula I.

Uji kerapuhan dilakukan dengan tujuan untuk mengukur ketahanan permukaan tablet terhadap gesekan sewaktu pengemasan dan pengiriman. 
Dari uji yang telah dilakukan diperoleh hasil bahwa ketiga formula memiliki persentase kerapuhan yang dipersyaratkan. Dari hasil tersebut menunjukkan bahwa formula I memiliki persentase kerapuhan yang paling kecil jika dibandingkan formula II dan formula III. Hal ini karena komposisi bahan dari formula I dapat mengatasi masalah kerapuhan tersebut, seperti halnya MCC yang bisa digunakan sebagai pegisi sekaligus pengikat dalam konsentrasi 20 $90 \% .{ }^{10}$

Faktor yang dapat mempengaruhi kerapuhan yakni kekerasan tablet dan karakteristik dari eksipien yang digunakan. Semakin besar persentase kerapuhan, maka semakin besar massa tablet yang hilang. Uji kerapuhan berhubungan dengan kehilangan bobot akibat abrasi (pengikisan) yang terjadi pada permukaan tablet. Kerapuhan yang tinggi akan mempengaruhi konsentrasi obat yang masih terdapat pada tablet. Pada tablet dengan konsentrasi obat yang kecil (tablet dengan bobot kecil), adanya kehilangan massa akibat rapuh akan mempengaruhi kadar obat yang masih terdapat dalam tablet. ${ }^{9}$ Berdasarkan hasil tersebut disimpulkan bahwa masing-masing formula memenuhi persyaratan kerapuhan yakni sebesar 1\%.8 Pada formula I yang memiliki kerapuhan paling kecil juga memiliki nilai kekerasan yang paling tinggi. Hal ini dapat dihubungkan bahwa semakin keras tablet kerapuhannya juga semakin kecil. Bila tablet tidak keras maka akan cenderung memiliki kerapuhan pada saat proses pengemasan. ${ }^{9}$

Uji laju pelepasan obat dilakukan untuk mengetahui seberapa banyak kadar obat yang terlepas dari sediaan secara kuantitatif per satuan waktu. Berdasarkan uji laju pelepasan obat yang telah dilakukan diperoleh hasil bahwa masing-masing formula mengalami peningkatan pelepasan obat tiap satuan waktu (Gambar 1). Formula I memiliki laju pelepasan obat yang lebih besar jika dibandingkan dengan formula II dan formula III. Formula III melepaskan lebih sedikit obat daripada formula I dan formula II. Hasil tersebut menunjukkan bahwa formula III yang memiliki konsentrasi tinggi polimer mukoadhesif menghambat laju pelepasan obat dibandingkan formula I dan formula II. Fungsi superdisintegran sendiri dapat dilihat dari ketiga formula bahwa pemecahan tablet terjadi secara cepat dan mampu melepaskan obat lebih dari $50 \%$ dalam waktu kurang dari 30 menit. Formula I lebih banyak melepaskan obat dalam 30 menit jika dibandingkan formula II dan formula III. Hal tersebut mengindikasikan bahwa formula I mampu meningkatkan jumlah obat yang terlepas dari sediaan.

Hasil laju pelepasan obat pada masing-masing formula memiliki kenaikan profil laju pelepasan yang signifikan, dilihat dari semakin meningkatnya kadar obat yang terlepas tiap satuan waktu (Gambar 1). Eksipien superdisintegran mampu meningkatkan jumlah obat yang terlepas tiap waktunya, sedangkan polimer mukoadhesif yang digunakan mampu berfungsi sebagai pembentuk ikatan antara obat dan area vagina. Hal ini terbukti dalam ketiga formula. Ketiga formula tidak terdispersi secara langsung ke dalam cairan uji dan melekat pada dasar tabung uji yang diibaratkan sebagai area vagina.

Pada uji laju pelepasan obat ini, penggunaan konsentrasi polimer HPMC 
yang berbeda juga mempengaruhi profil laju pelepsan obat. Semakin tinggi konsentrasi HPMC semakin kuat ikatan yang terbentuk dan semakin lama waktu kontak dengan mukosa daerah vagina. $6 \mathrm{Hal}$ ini terlihat pada formula 3 dengan konsentrasi HPMC sebesar $50 \%$ menghambat pelepasan obat dari sediaan dengan jumlah obat yang terlepas dari sediaan per satuan waktu lebih kecil jika dibandingkan dengan formula I dan formula II. Pada formula I dan formula II yang menggunakan konsentrasi HPMC sebesar 30\% memiliki laju pelepasan obat yang lebih besar. Akan tetapi formula I lebih banyak jumlah yang terlepas jika dibandingkan dengan formula II. Hal ini diperkirakan karena penggunaan superdisintegran dengan konsentrasi yang berbeda. Crosscar mellose sodium memecah tablet dengan proses swelling membentuk lapisan gel tipis. Bila konsentrasinya lebih besar maka lapisan gel yang terbentuk juga lebih tebal. Oleh karena itu, bisa menghambat pelepasan obat dengan adanya lapisan gel tersebut.

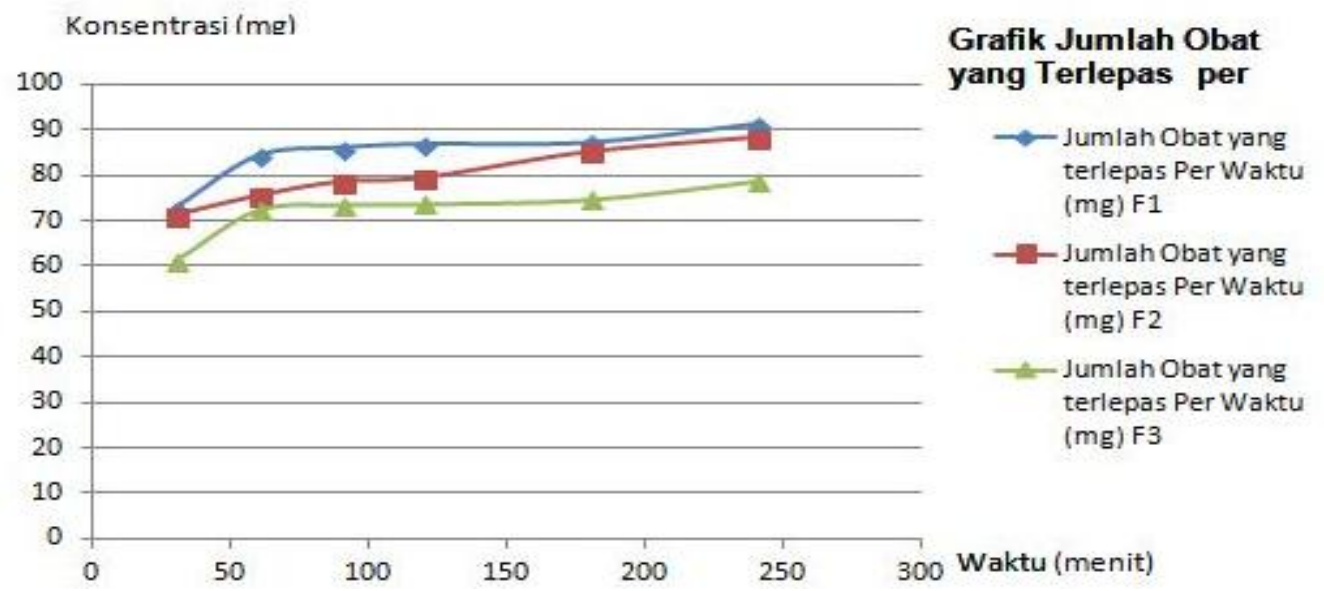

Gambar 1. Jumlah obat yang terlepas per satuan waktu

Uji pengembangan dilakukan untuk mengetahui seberapa banyak tablet bisa mengembang dari sediaan. Hal ini juga berkaitan dengan bahan mukoadhesif yang digunakan yakni HPMC. Uji ini dilakukan untuk mengetahui besarnya peregangan dalam polimer HPMC setelah terbasahi oleh buffer sitrat dan untuk penetrasi polimer ke dalam jaringan sehingga memungkinkan untuk membentuk ikatan hidrogen dengan mukosa vagina. Hasil uji yang dilakukan menunjukkan bahwa ketiga formula memiliki indeks pengembangan yang tidak berbanding lurus dengan waktu. Formula III memiliki indeks pengembangan paling besar daripada formula I dan formula II (Tabel 2). Hasil tersebut menunjukkan bahwa formula III yang memiliki konsentrasi tinggi polimer mukoadhesif mampu berfungsi dengan baik sebagai polimer yang mampu mengembangkan tablet dengan maksimal untuk membantu proses pengikatan obat di daerah vagina dan membantu proses pelepasan obat. Pada Gambar 2. menunjukkan bahwa indeks pengembangan tablet mengalami kenaikan mulai 
pada menit ke-15 hingga menit ke-120, kemudian mengalami penurunan pada menit ke-240. Hal tersebut menunjukkan bahwa pada menit ke-60 dan ke-120 merupakan pengembangan yang paling maksimal dari ketiga tablet. Akan tetapi kenaikan tersebut tidak konstan terjadi selama beberapa waktu. Hal ini bisa diakibatkan oleh beberapa hal yaknipada saat diletakkan pada oven untuk pengoptimalan suhu wadah tidak tertutup sehingga cairan dari wadah bisa terpenetrasi keluar dan tablet menjadi mengering. Selain itu, wadah percobaan yang tidak sama sehingga mengakibatkan proses pengembangan tidak maksimal.
Berdasarkan hal tersebut dapat dilihat bahwa formula III yang memiliki indeks pengembangan tablet yang paling besar mengakibatkan terhambatnya pelepasan obat dari sediaan, sehingga jumlah obat yang terlepas dari sediaan lebih sedikit jika dibandingkan dengan formula I dan formula II. Sementara itu formula I yang memiliki indeks pengembangan paling kecil mampu melepaskan obat dalam jumlah yang banyak. Dengan demikian, dapat ditarik hubungan bahwa pengembangan tablet mempengaruhi laju pelepasan obat.

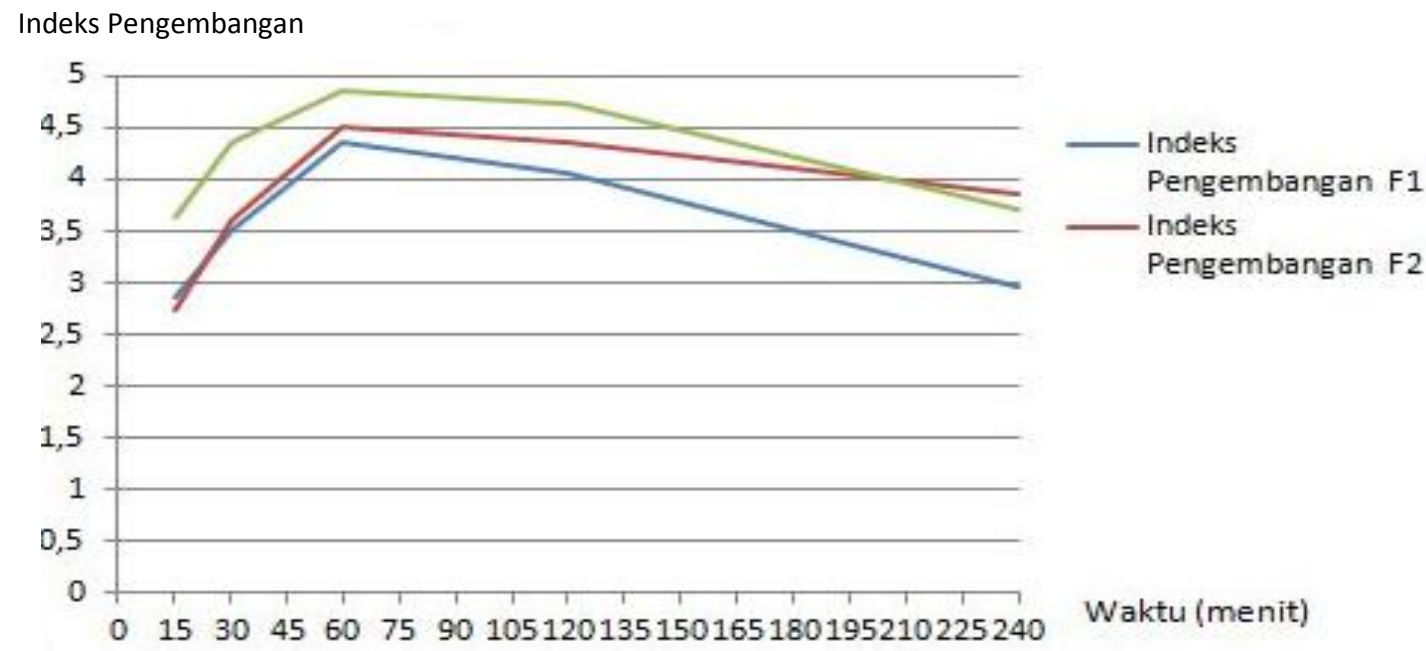

Gambar 2. Uji pengembangan tablet

Uji kemampuan mukoadhesif dilakukan dengan tujuan untuk mengetahui seberapa kuat tablet bisa terikat dalam mukosa vagina. Alat yang digunakan yakni tensile strenght. Mukosa usus digunakan sebagai pengganti mukosa vagina yang direndam pada larutan $\mathrm{NaCl}$ 0,9\% untuk tetap menjaga kondisi usus agar tetap terjaga. Dalam pengujian ini dapat terlihat daya adhesif tablet vaginal dengan adanya gaya berupa beban yang melepas ikatan antara tablet dengan usus. Hal ini disebabkan karena adanya interaksi berupa ikatan hidrogen antara polimer HPMC dan usus kelinci. ${ }^{11}$ Dari hasil uji yang dilakukan diperoleh hasil bahwa formula III memiliki daya adhesive yang paling tinggi diantara ketiga formula. Hal ini sesuai dengan asumsi bahwa semakin tinggi konsentrasi polimer yang terkandung dalam formula daya adhesif juga semakin meningkat. 
Daya adhesive yang tinggi pada formula III menyebabkan laju pelepasan obat berjalan dengan lambat. Hal ini dikarenakan polimer HPMC mempunyai mekanisme pengikatan ke dalam mukosa vagina dengan metode pembentukan lapisan gel. Dalam proses pembentukan gel, cairan berpenetrasi ke dalam tablet dan matriks HPMC hidrofilik hidrat, yang menyebabkan terjadinya hidrasi dan peregangan rantai sehingga matriks tersebut dapat mengembang dan berubah bentuk seperti lapisan gel kental sehingga bisa membentuk ikatan dengan lapisan mukosa, akan tetapi justru menghambat proses pelepasan obat. ${ }^{6}$ Sementara formula I dan formula || dengan konsentrasi polimer sebesar 30 $\%$ memiliki daya adhesif lebih rendah karena pengikatan yang terbentuk jugatidak sekuat formula III yang memiliki konsentrasi $50 \%$. Hal ini juga berakibat pada pelepasan obat yang tidak terhambat, sehingga jumlah obat yang terlepas per satuan waktu lebih besar jika dibandingkan formula III. Uji penetapan kadar dilakukan dengan tujuan untuk mengetahuikadar obat metronidazol dalam tablet vaginal apakah sesuai dengan dosis yang diinginkan. Setelah dilakukan uji penetapan kadar ketiga formula memenuhi persyaratan penerimaan yakni dengan kadar obat sesuai dengan rentang sebesar $90-110 \%$ yang berarti bahwa obat pada ketiga formula telah tersebar secara merata dan telah memenuhi dosis yang telah ditentukan untuk mencapai efek terapi. Penetapan kadar obat dalam sebuah tablet mempengaruhi keberhasilan dari efektifitas terapi yang digunakan oleh pasien. Bila obat tidak sesuai dengan yang tertera pada dosis yang telah ditentukan bisa mengakibatkan kegagalan terapi dan akan berbahaya bagi pasien.

Daya hancur penting untuk tablet yang mengandung bahan obat yang tidak dimaksudkan untuk diabsorpsi. Dalam hal ini daya hancur tablet memungkinkan partikel obat menjadi lebih luas untuk bekerja secara lokal dalam tubuh. Waktu hancur dapat dipengaruhi oleh bahan penghancur/ disintegran (jenis dan jumlahnya) dan banyaknya pengikat yang digunakan dalam formulasi tablet, karena disintegran merupakan bahan yang akan menyebabkan tablet pecah dan hancur dalam air atau cairan lambung. ${ }^{9}$ Tablet yang memiliki waktu hancur yang sesuai dengan persyaratan yang telah ditetapkan dapat memberikan efek terapi yang cepat. Waktu yang diperbolehkan untuk menghancurkan tablet vaginal adalah tidak lebih dari 30 menit.

Dari uji yang telah dilakukan didapatkan hasil bahwa ketiga formula memenuhi kriteria penerimaan waktu hancur tablet vaginal yakni $<30$ menit. Hasil tersebut menunjukkan bahwa formula II memiliki waktu hancur yang paling cepat daripada formula I dan formula III karena memiliki konsentrasi superdisintegran yang paling besar yakni $3 \%$. Waktu hancur sediaan tablet sangat berpengaruh dalam fase biofarmasi obat. Supaya obat sepenuhnya diabsorpsi, maka tablet harus hancur ke dalam cairan tubuh untuk dilarutkan. ${ }^{9}$

\section{PEMBAHASAN}

Berdasarkan uji yang telah dilakukan meliputi uji IPC dan uji sediaan tablet vaginal metronidazol diperoleh hasil bahwa kombinasi kadar HPMC dan 
crosscarmellose sodium dalam tablet vaginal metronidazol mempengaruhi daya adhesif dan proses pelepasan obat dari sediaan. Aplikasi sediaan vagina harus mampu bertahan lebih dari 3 jam untuk melihat keefektifan dari polimer mukoadhesif dan juga melihat profil pelepasan obat.12 Tablet vaginal metronidazol dengan kombinasi polimer dan superdisintegran ini ternyata mampu memberikan profil peningkatan laju pelepasan tiap satuan waktunya. Bila laju pelepasannya meningkat maka dapat diasumsikan bahwa obat yang terpenetrasi ke dalam vagina juga banyak, sehingga infeksi jamur maupun bakteri dapat segera teratasi. Selain itu, daya adhesif tablet juga tinggi. Hal ini berarti obat mampu bertahan dalam vagina selama lebih dari 3 jam. Akan tetapi untuk dosis dan durasi terapi yang diberikan perlu penelitian lebih lanjut untuk mengetahui efektivitas sediaan. $\mathrm{Hal}$ tersebut di atas didukung dari beberapa penelitian yakni dalam sebuah penelitian diketahui bahwa tanpa penggunaan superdisintegran, obat akan semakin lama terlepas dari sediaan dan memiliki daya adhesif yang tinggi. Dengan nilai penggunaan HPMC sebesar $30 \%$, pelepasan $80 \%$ obat terjadi dalam waktu $>500$ menit. Sementara untuk konsentrasi HPMC sebesar $50 \%$, pelepasan $80 \%$ obat terjadi dalam $>700$ menit. ${ }^{13}$ Dengan demikian profil pelepasan obat dengan metode kombinasi polimer dan superdisintegran pada penelitian ini sangat membantu laju pelepasan obat pada saat awal pemberian obat dengan memecah sediaan secara cepat, namun tetap memiliki daya adhesif yang tinggi dengan tetap berada dalam daerah vagina selama 4 jam. Hal ini dapat terlihat dalam formula I tablet vaginal metronidazol. Dengan konsentrasi HPMC sebesar $30 \%$ dan crosscarmellose sodium sebesar $1 \%$ mampu memecah obat secara cepat, sehingga laju pelepasan obat dalam kurun waktu 30 menit pada saat awal pemberian dapat terjadi secara cepat dan obat tetap mempunyai laju pelepasan yang tetap pada kurun waktu 3 jam berikutnya. Akan tetapi perlu ditinjau lebih jauh apakah dengan penggunaan tablet vaginal dalam 4 jam yang dapat melepas obat sebesar 91,11 mg bisa mengefektifkan dan mengoptimalkan terapi. Karena biasanya sediaan tablet vaginal yang telah dipasarkan mempunyai durasi terapi 1 kali sehari. ${ }^{14}$ Selain itu, perlu dilakukan lebih lanjut pula apakah dengan dosis $100 \mathrm{mg}$ per tablet dapat lebih efektif jika dibandingkan dengan sediaan tablet vaginal konvensional lain yang telah beredar di pasaran.

Daya pengembangan pada tablet vaginal mempengaruhi proses difusi obat dari tablet ke sistem dan daya adhesif. Bila tablet tidak mempunyai daya pengembangan yang baik maka proses pelepasan obat dan daya adhesif ke dalam sistem juga akan terganggu. Semakin tebal lapisan gel yang terbentuk karena proses pengembangan juga menghambat proses pelepasan obat, namun memperkuat ikatan yang terbentuk. HPMC memiliki campuran dari alkil hidroksialkil selulosa eter yang terdiri dari gugus metoksi dan hidroksipropil. Substitusi dari gugusgugus tersebut yang menyebabkan perbedaan sifat fisika kimia seperti laju dan lamanya proses hidrasi, biodegradasi, aktivitas permukaan dan sifat kekenyalannya. Bahan obat dan 
bahan tambahan lainnya secara kesatuan diikat oleh HPMC dan kemudian dicetak menjadi bentuk sediaan. Dalam proses pengembangan, cairan berpenetrasi ke dalam tablet dan matriks HPMC hidrofilik hidrat, yang menyebabkan terjadinya hidrasi dan peregangan rantai sehingga matriks tersebut dapat mengembang dan berubah bentuk seperti lapisan gel kental. Lapisan gel tersebut akan mengontrol proses difusi air ke dalam sistem dan proses difusi obat keluar dari sistem. Pada periode yang lama, lapisan tersebut akan pecah dan larut sehingga air dapat berpenetrasi lebih dalam ke matriks, berubah manjadi lapisan gel yang baru. Proses ini berlangsung terusmenerus hingga seluruh matriks hidrofilik larut. Matriks bentuk gel ini secara efektif dapat menjerat bahan aktif dan memperlambat pelepasannya, yang dapat terjadi dengan proses difusi melalui lapisan gel dan atau erosi matriks gelitu sendiri. ${ }^{15}$

Desain formulasi tablet vaginal harus bertujuan untuk memberikan erosi tablet dalam cairan vagina, sehingga bisa meningkatkan efektivitasnya. Selain itu sediaan untuk rute vagina harus tetap mampu menjaga $\mathrm{pH}$ normal vagina. ${ }^{16}$ Kenyamanan bagi pasien ketika penggunaan tablet vaginal amat diperhatikan. Tablet vaginal harus segera dapat berikatan dengan mukus sehingga tidak terjadi aksi self-cleansing dari area vagina pada tablet vaginal itu sendiri. Hal tersebut otomatis mempengaruhi efektifitas terapi dari tablet vaginal. ${ }^{1}$ Sediaan tablet vaginal haruslah cepat terdisintegrasi untuk menghindari hal tersebut. Penambahan superdisintegran terbukti telah memberikan efek yang diharapkan dengan mempercepat waktu disintegrasi sehingga pelepasan obat dapat meningkat. Penggunaan effervescent sebagai bahan pembantu pengembangan tablet hanya mampu melepaskan obat kurang dari $60 \%$ selama 60 menit. ${ }^{17}$ Sementara dalam penelitian ini, penambahan superdisintegran mampu meningkatkan jumlah obat yang terlepas obat dari sediaan dengan jumlah obat yang terlepas sebesar lebih dari $70 \mathrm{mg}$ dalam 60 menit.

\section{KESIMPULAN}

Komposisi formula yang optimum untuk tablet vaginal metronidazole adalah $30 \%$ polimer HPMC dan 1\% superdisintegran crosscarmellose sodium, dengan laju pelepasan obat sebesar 0,1257 $\mathrm{mg} / \mathrm{menit}$ dalam waktu 4 jam dan mengalami peningkatan sejak awal waktu uji serta menghasilkan daya adhesif yang tetap mampu mempertahankan pelepasan obat selama 4 jam.

\section{DAFTAR PUSTAKA}

1. Ambikar RB and Doekar GS. Design and In-vitro Evaluation of Benzydamine Hydrochloride Rapidly Dispersible Gel Forming Tablets for Vaginal Delivery. Universal Journal of Pharmacy. 2014; 03(01):79-85.

2. Pandey KH. Formulation and In-vitro Evaluation of Antibiotic Effervescent Bioadhesive Vaginal Tablet. Karnakata: Department of Pharmaceutics, The Oxford College of Pharmacy. 2012.

3. Phanindra B, et al. Recent Advances in Mucoadhesive/Bioadhesive Drug Delivery System : A Review. Int J Pharm Med \& Bio Sc. 2013; 2(1). 
4. Geeta PM and Patel AP. A Novel Effervescent Bioadhesive Vaginal Tablet of Ketoconazole : Formulation and In-vitro Evaluation. International Journal of PharmTech Research. 2010; 2(1):656-667.

5. Priyanka Sand Sethi V. A Review Article On: Superdisintegran. Int J Drug Res Tech. 2013; 3(4).

6. Akbari J, et al. Development and Evaluation of Mucoadhesive Chlorhexidine Tablet Formulations.Tropical Journal of Pharmaceutical Research. 2010; 9(4):321-327.

7. Lachman L. The Theory \& Practice of Industrial Pharmacy. English: Lea \& Febiger. 1986.

8. The United States Pharmacopeial Convention. 2007. United States Pharmacopoeia XXX.

9. Banne $Y$, et al. Uji Kekerasan, Keregasan, dan Waktu Hancur Beberapa Tablet Ranitidin. Manado: Jurusan Farmasi Politeknik Kesehatan Kemenkes. 2012.

10. Rowe, et al. Handbook of Pharmaceutical Excipients. ${ }^{\text {th }}$ Edition. London: Royal Pharmaceutical Society of Great Britain. 2009.

11. El-Kamel, Amal Hasan, et al. Biodhesive Controlled Release Metronidazole Vaginal Tablets. Acta Pharm. 2002; 52:171-179.

12. Karaskulu $\mathrm{H}$, Yesim, et al. Efficacy of a New Ketoconazole Bioadhesive Vaginal Tablet on Candida albicans. IL FARMACO. 2004; 59:163-167.

13. Sheskey PJ and Hendren J. The Effects of Roll Compaction Equipment Variables, Granulation Technique, and HPMC Polymer Level on A Controlled-Release
Matrix Model Drug Formulation. Pharm Technol. 1999;23(3):90-106.

14. Swarbick J, et al. Encyclopedia of Pharmaceutical Technology. Vol 1. $3^{\text {rd }}$ Edition. New York: Marcel Dekker Inc. 2007.

15. Jones D. Pharmaceutical Application of polymers for Drug Delivery. Vol 15. Rapra. 2004.

16. Lieberman, et al. 1989. Pharmaceutical Dosage Form: Tablet. Vol 1. New York: Marcel Dekker, Inc.

17. Patel DB, et al. Formulation and Development of Mucoadhesive Tablet of Diltiazem Hydrocloride. International Journal of Pharma and Bio Sciences. 2010; 1(2). 